\title{
Crystal structure of metal (I) bromide complexes containing 1-(4-nitrophenyl)thiourea and triphenylphosphine ligands
}

\author{
Yupa Wattanakanjana $^{\mathrm{a}, *}$, Walailak Puetpaiboon ${ }^{\mathrm{a}}$, Paramee Sripa ${ }^{\mathrm{a}}$, Arunpatcha Nimthong-Roldan ${ }^{\mathrm{b}}$ \\ a Department of Chemistry, Faculty of Science, Prince of Songkla University, Songkhla 90112 Thailand \\ b Pre-Development Sciences, Waltham, Massachusetts 02451 USA
}

*Corresponding author, e-mail: yupa.t@psu.ac.th

Received 16 Oct 2019

Accepted $18 \mathrm{Feb} 2020$

\begin{abstract}
Two metal(I) complexes containing triphenylphosphine $\left(\mathrm{PPh}_{3}\right)$ and 1-(4-nitrophenyl)thiourea (NPTU) ligands were prepared, namely, $\left[\mathrm{MBr}(\mathrm{NPTU})\left(\mathrm{PPh}_{3}\right)_{2}\right](\mathrm{M}=\mathrm{Cu}(1)$ and $\mathrm{Ag}(2))$. Both compounds (1) and (2) exhibit a distorted tetrahedral metal coordination environment with two $\mathrm{P}$ atoms from two $\mathrm{PPh}_{3}$ ligands, one terminal $\mathrm{S}$ atom from the NPTU ligand and a bromide ion. An intramolecular $\mathrm{N}-\mathrm{H} \cdots$ Br hydrogen bond is observed (graph set motif $\mathrm{S}(6)$ ). Amine and bromide units from neighbouring molecules are linked via bifurcated $(\mathrm{N}-\mathrm{H})_{2} \cdots$ Br hydrogen bonds forming 1D zigzag chains along [001] with an $\mathrm{R}_{1}^{2}(6)$ graph set motif. Neighbouring chains are connected through $\mathrm{C}-\mathrm{H} \cdots \mathrm{O}$ hydrogen bonds leading to the formation of a three-dimensional network.
\end{abstract}

KEYWORDS: silver(I) bromide, copper(I) bromide, 1-(4-nitrophenyl)thiourea, hydrogen bonding, intra- and intermolecular hydrogen bonding

\section{INTRODUCTION}

Thiourea and thiourea derivatives have attracted considerable attention in recent years as a class of ligands that bear both soft sulfur and hard nitrogen donor atoms, as defined by the HSAB (hard and soft acids and bases) concept. This gives thiourea and its analogues a wide range of possible coordination modes towards metal ions, allowing both coordination towards soft metals, such as copper [1], silver [2], gold [3] and palladium [4] via its sulfur donor site. The acidic hydrogen atoms of the amine moiety provide additional means of inter- or intramolecular interactions via formation of hydrogen bonds, giving this class of compounds, an even wider range of structural diversity.

Thiourea and thiourea derivatives including its metal complexes are also relevant due to their observed biological properties, such as antiproliferative activity against lung cancer cells and antitumor agents [5]. Some derivatives were also found to exhibit a moderate inhibitory potency on the diphenolase activity of tyrosinase [6] and against biofilm formation [7]. Copper(I) and silver(I) complexes of thiourea derivatives have been studied for their antimycobacterial, antileishmanial, antibacterial [8] and antifungal activities [9]. Keeping these potential applications in mind we recently reported a series of metal thiourea complexes prepared by reacting copper or silver(I) chloride with triphenylphosphane and 1-(4-nitrophenyl)thiourea, NPTU $[10,11]$. Herein, we report the synthesis and crystal structures of analogue bromide compounds $\left[\mathrm{MBr}(\mathrm{NPTU})\left(\mathrm{PPh}_{3}\right)_{2}\right](\mathrm{M}=\mathrm{Cu}$ and $\mathrm{Ag})$.

\section{MATERIALS AND METHODS}

\section{Materials}

Reagent and solvents in the synthesis were obtained from commercial suppliers and used directly without further purification. Copper(I) bromide, silver(I) bromide, triphenylphosphine and 1-(4nitrophenyl)thiourea were purchased from Sigma Aldrich. Infrared spectra were measured in the region $4000-400 \mathrm{~cm}^{-1}$ on a Perkin-Elmer $783 \mathrm{In}$ frared Spectrophotometer using potassium bromide pellets.

\section{Synthesis of $\left[\mathrm{CuBr}(\mathrm{NPTU})\left(\mathrm{PPh}_{3}\right)_{2}\right](1)$}

Triphenylphosphane $(0.16 \mathrm{~g}, 0.61 \mathrm{mmol})$ was dissolved in $30 \mathrm{~mL}$ of acetonitrile at $339 \mathrm{~K}$ and then copper(I) bromide (0.04 g, $0.28 \mathrm{mmol}$ ) was added. The mixture was stirred for $2 \mathrm{~h}$ and then 1-(4nitrophenyl)thiourea, (0.06 g, $0.30 \mathrm{mmol}$ ) was 
added. The resulting reaction mixture was heated under reflux for $6 \mathrm{~h}$ during which the precipitate gradually disappeared. The resulting clear solution was filtered and left to evaporate at room temperature. A yellow crystalline precipitate was obtained upon standing for three days, and was filtered off and dried in vacuo ( $0.11 \mathrm{~g}, 42 \%$ yield). M.p. 469-471 K. IR bands (KBr, $\left.\mathrm{cm}^{-1}\right): 3248(\mathrm{~m})$, 3134 (m), 2673 (m), 1963 (w), 1893 (w), 1816 (w), 1774 (w), 1597 (s), 1577 (s), 1511 (s), 1478 (s), 1400 (s), 1328 (m), 1178 (w), $1154(\mathrm{w}), 1093$ (w), $1027(w), 996(w), 887(w), 849(s), 745(s)$, 693 (s).

\section{Synthesis of $\left[\mathrm{AgBr}(\mathrm{NPTU})\left(\mathrm{PPh}_{3}\right)_{2}\right](2)$}

Triphenylphosphane $(0.16 \mathrm{~g}, 0.61 \mathrm{mmol})$ was dissolved in $30 \mathrm{~mL}$ of acetonitrile at $339 \mathrm{~K}$ and then silver(I) bromide (0.06 g, $0.30 \mathrm{mmol})$ was added. The mixture was stirred for $3 \mathrm{~h}$ and then 1-(4nitrophenyl)thiourea, (0.05 g, $0.25 \mathrm{mmol}$ ) was added. The resulting reaction mixture was heated under reflux for $7 \mathrm{~h}$ during which the precipitate gradually disappeared. The resulting clear solution was filtered and left to evaporate at room temperature. The yellow crystalline complex, which deposited upon standing for a day, was filtered off and dried in vacuo $(0.18 \mathrm{~g}, 67 \%$ yield). M.p. 451$453 \mathrm{~K}$. IR bands $\left(\mathrm{KBr}, \mathrm{cm}^{-1}\right): 3296(\mathrm{~m}), 3248(\mathrm{~m})$, $3135(\mathrm{~m}), 2346(\mathrm{w}), 1578(\mathrm{w}), 1508(\mathrm{w}), 1492(\mathrm{w})$, $1478(\mathrm{w}), 1432$ (m), 1399 (m), 1333 (s), $1296(\mathrm{w})$, $1255(\mathrm{w}), 1180(\mathrm{w}), 1156(\mathrm{w}), 1094(\mathrm{~m}), 1026(\mathrm{w})$, $997(\mathrm{w}), 849(\mathrm{~m}), 745(\mathrm{~s}), 693(\mathrm{~s})$.

\section{X-ray crystallographic analysis}

X-ray diffraction data for 1 and 2 was obtained on a Bruker Quest diffractometer with Mo- $K \alpha$ radiation $(\lambda=0.71073 \AA)$ at $150 \mathrm{~K}$ and $100 \mathrm{~K}$, respectively. Data were collected; reflections were indexed and processed using APEX3 [12]. The space groups were assigned and the structures were solved by direct methods using XPREP within the SHELXTL suite of programs $[13,14]$ and refined using Shelxl [15] and Shelxle [16] (Table 1). Refinement for 1: crystal data, data collection and structure refinement details are summarized in Table 1 . All $\mathrm{H}$ atoms attached to carbon atoms were positioned geometrically and constrained to ride on their parent atoms, with $\mathrm{C}-\mathrm{H}=0.95 \AA$. The nitrogen bound $\mathrm{H}$ atoms were located in difference-Fourier maps and were refined with an $\mathrm{N}-\mathrm{H}=0.84(2)-0.85(2) \AA . U_{\text {iso }}(\mathrm{H})$ values were set to $1.2 U_{\mathrm{eq}}(\mathrm{C} / \mathrm{N})$. Refinement for 2 :

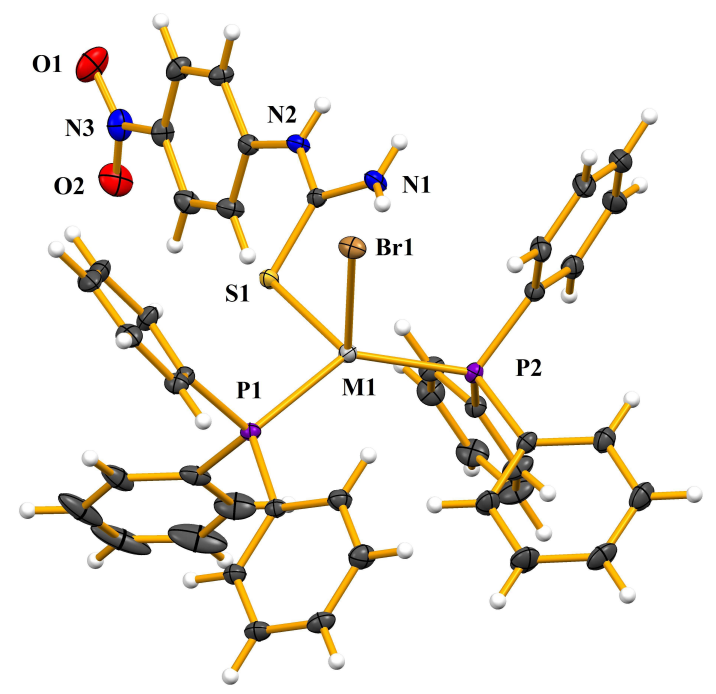

Fig. 1 The molecular structure of $\left[\mathrm{MBr}(\mathrm{NPTU})\left(\mathrm{PPh}_{3}\right)_{2}\right]$ ( $\mathrm{M}=\mathrm{Cu}(1)$ and $\mathrm{Ag}(2))$, with displacement ellipsoids drawn at the $50 \%$ probability level.

crystal data, data collection and structure refinement details are summarized in Table 1 . All $\mathrm{H}$ atoms attached to carbon atoms were positioned geometrically and constrained to ride on their parent atoms, with $\mathrm{C}-\mathrm{H}=0.95 \AA$ A. The nitrogen bound $\mathrm{H}$ atoms were located in difference-Fourier maps and were refined with an $\mathrm{N}-\mathrm{H}=0.83(2)-0.85(2) \AA . . U_{\text {iso }}(\mathrm{H})$ values were set to $1.2 U_{\mathrm{eq}}(\mathrm{C} / \mathrm{N})$. Reflections 040 , $031,-302,-131,130,-81018,-10317$, and -9217 were affected by the beam stop and were omitted from the refinement. CCDC 1981594 (for 1) and 1981339 (for 2) contain the supplementary crystallographic data for this paper. These data can be obtained free of charge from The Cambridge Crystallographic Data Center.

\section{RESULTS AND DISCUSSION}

The $\left[\mathrm{MBr}(\mathrm{NPTU})\left(\mathrm{PPh}_{3}\right)_{2}\right](\mathrm{M}=\mathrm{Cu}(1)$ and $\mathrm{Ag}(2))$ complexes as well as their chloride counterparts are isostructural and isomorphous. The thiourea is coordinated to both $\mathrm{Cu}$ and $\mathrm{Ag}$ solely via the soft sulfur donor, and no interaction of the metal with the amine moiety is observed. The complexes are monomeric, metal ions are not bridged via either the sulfur or bromide ions, and in both compounds, the $\mathrm{M}(\mathrm{I})$ ion is coordinated to exactly two $\mathrm{P}$ atoms from two $\mathrm{PPh}_{3}$ ligands, one terminal $S$ atom from the NPTU ligand and one bromide ion, leading to a distorted tetrahedral 
Table 1 Experimental details.

\begin{tabular}{|c|c|c|c|c|}
\hline \multicolumn{5}{|l|}{ Crystal data } \\
\hline Chemical formula & & \multicolumn{2}{|c|}{$\mathrm{C}_{43} \mathrm{H}_{37} \mathrm{CuBrN}_{3} \mathrm{O}_{2} \mathrm{P}_{2} \mathrm{~S}$} \\
\hline & \multicolumn{2}{|c|}{909.53} & \multicolumn{2}{|c|}{865.20} \\
\hline Crystal system, space group & \multicolumn{2}{|c|}{ Monoclinic $P 2_{1 / c}$} & \multicolumn{2}{|c|}{ Monoclinic $P 2_{1 / c}$} \\
\hline Temperature (K ) & \multicolumn{2}{|c|}{100} & \multicolumn{2}{|c|}{150} \\
\hline $\mathrm{a}, \mathrm{b}, \mathrm{c}(\AA)$ & \multicolumn{2}{|c|}{11.7913 (5), 28.6891 (11), 12.1416 (5) } & \multicolumn{2}{|c|}{$11.6696(5), 29.0515(10), 12.0068$ (5) } \\
\hline$\beta\left(^{\circ}\right)$ & \multicolumn{2}{|c|}{$105.1249(16)$} & \multicolumn{2}{|c|}{$106.351(2)$} \\
\hline$V(\AA 3)$ & \multicolumn{2}{|c|}{$3965.0(3)$} & \multicolumn{2}{|l|}{$3905.9(3)$} \\
\hline$Z$ & \multicolumn{2}{|l|}{4} & \multicolumn{2}{|l|}{4} \\
\hline Radiation type & \multicolumn{2}{|l|}{ Mo-K $\alpha$} & \multicolumn{2}{|l|}{ Mo- $K \alpha$} \\
\hline$\mu\left(\mathrm{mm}^{-1}\right)$ & \multicolumn{2}{|l|}{1.69} & \multicolumn{2}{|l|}{1.76} \\
\hline Crystal size (mm) & \multicolumn{2}{|c|}{$0.45 \times 0.43 \times 0.36$} & \multicolumn{2}{|c|}{$0.38 \times 0.36 \times 0.30$} \\
\hline \multicolumn{5}{|l|}{ Data collection } \\
\hline Diffractometer & \multicolumn{2}{|c|}{ Bruker AXS D8 Quest CMOS } & \multicolumn{2}{|c|}{ Bruker AXS D8 Quest CMOS } \\
\hline Absorption correction & \multicolumn{2}{|c|}{ Multi-scan Apex3 v2016.9-0 } & \multicolumn{2}{|c|}{ Multi-scan Apex3 v2016.9-0 } \\
\hline $\begin{array}{l}\text { No. of measured, independent, } \\
\text { observed }[I>2 \sigma(I)] \text { reflections }\end{array}$ & 53040 & & 46975,11816 , & \\
\hline Rint & 0.021 & & 0.043 & \\
\hline$(\sin \theta / \lambda) \max (\AA-1)$ & 0.834 & & 0.770 & \\
\hline Refinement & & & & \\
\hline$R[F 2>2 \sigma(F 2)], w R(F 2), S$ & 0.027, & & $0.032,0.087,1$ & \\
\hline No. of reflections & 17948 & & 11816 & \\
\hline No. of parameters & 487 & & 490 & \\
\hline H-atom treatment & $\begin{array}{l}\text { a mixtu } \\
\text { constra }\end{array}$ & $\begin{array}{l}\text { ndent and } \\
\text { ent }\end{array}$ & $\begin{array}{l}\text { a mixture of in } \\
\text { constrained ref }\end{array}$ & \\
\hline$\Delta \rho \max , \Delta \rho \min (\mathrm{e} \AA-1)$ & $0.62,-$ & & $0.42,-0.83$ & \\
\hline $\begin{array}{l}\text { Computer programs: Apex3 } \\
\text { cury [19], SHELXL97, and pu }\end{array}$ & $\begin{array}{l}\text { SAINT } \\
1 \text { blCIF }[20\end{array}$ & S9 [13], SHELXL20 & 4/7 [15], SHF & 4 [16], Mer- \\
\hline$D-\mathrm{H} \cdots A$ & $D-\mathrm{H}$ & $\mathrm{H} \cdots A$ & $D \cdots A$ & $D-\mathrm{H} \cdots A$ \\
\hline Compound (1) & & & & \\
\hline $\mathrm{N} 1-\mathrm{H} 1 A \cdots \mathrm{Br} 1^{\mathrm{i}}$ & $0.85(2)$ & $2.48(2)$ & $3.3027(15)$ & $165(2)$ \\
\hline $\mathrm{N} 1-\mathrm{H} 1 B \cdots \mathrm{Br} 1$ & $0.84(2)$ & $2.54(2)$ & $3.3412(15)$ & $160(2)$ \\
\hline $\mathrm{N} 2-\mathrm{H} 2 \cdots \mathrm{Br} 1^{\mathrm{i}}$ & $0.84(2)$ & $2.63(2)$ & $3.4355(15)$ & $160(2)$ \\
\hline $\mathrm{C} 24-\mathrm{H} 24 \cdots \mathrm{O} 2^{\mathrm{ii}}$ & 0.95 & 2.61 & 3.33 & 134 \\
\hline $\mathrm{C} 33-\mathrm{H} 33 \cdots \mathrm{O} 1^{\mathrm{iii}}$ & 0.95 & 2.72 & 3.40 & 129 \\
\hline Compound (2) & & & & \\
\hline $\mathrm{N} 1-\mathrm{H} 1 A \cdots \mathrm{Br} 1^{\mathrm{i}}$ & $0.83(2)$ & $2.53(2)$ & $3.3186(12)$ & 158.3 (19) \\
\hline $\mathrm{N} 1-\mathrm{H} 1 B \cdots \mathrm{Br} 1$ & $0.85(2)$ & $2.60(2)$ & 3.3989 (12) & $157.3(18)$ \\
\hline $\mathrm{N} 2-\mathrm{H} 2 \cdots \mathrm{Br} 1^{\mathrm{i}}$ & $0.83(2)$ & $2.57(2)$ & $3.3734(11)$ & 162.8 (19) \\
\hline $\mathrm{C} 24-\mathrm{H} 24 \cdots \mathrm{O} 2^{\mathrm{ii}}$ & 0.95 & 2.62 & 3.277 & 127 \\
\hline $\mathrm{C} 33-\mathrm{H} 33 \cdots \mathrm{O} 1^{\mathrm{iii}}$ & 0.95 & 2.68 & 3.398 & 133 \\
\hline
\end{tabular}

Symmetry codes: (i) $x,-y+1 / 2, z-1 / 2$; (ii) $-x+1,-y+1,-z+1$; (iii) $x-1, y, z$.

environment (Fig. 1). The monomeric structures are stabilized by an intramolecular $\mathrm{N} 1-\mathrm{H} 1 B \cdots \mathrm{Br} 1$ hydrogen bond between the NPTU $\mathrm{NH}_{2}$ and the $\mathrm{Br}$ atom, thus saturating the donor sites of the bromide ions and making them unavailable for possible dimer formation via bridging halogens as often observed in other silver(I) of copper(I) species where no such hydrogen bonds are observed. The graph-set motif of the $\mathrm{N}-\mathrm{H} \cdots \mathrm{Br}$ hydrogen bond is $\mathrm{S}(6)$ (Table 2 ). The $\mathrm{Cu}-\mathrm{S}$ distance in (1) is similar to the values of 2.382 (2) $\AA$ reported in $\left[\mathrm{CuCl}\left(\mathrm{C}_{7} \mathrm{H}_{7} \mathrm{~N}_{3} \mathrm{O}_{2} \mathrm{~S}\right)\left(\mathrm{C}_{18} \mathrm{H}_{15} \mathrm{P}\right)_{2}\right]$. The 


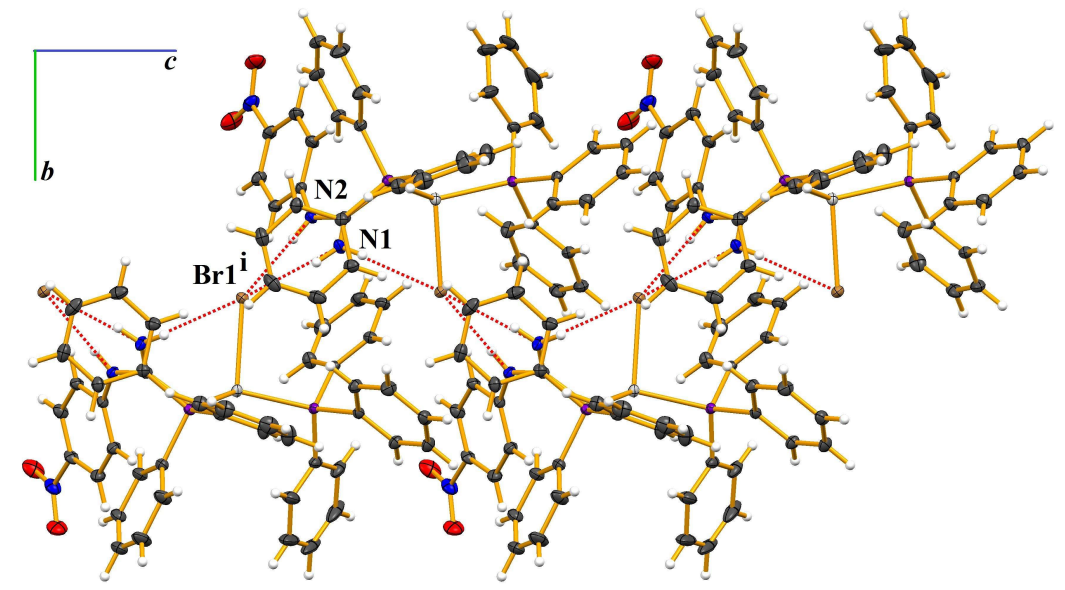

Fig. 2 Part of the crystal structure of [AgBr(NPTU) $\left(\mathrm{PPh}_{3}\right)_{2}$ ], showing the 1D zigzag chain along [001] axis formed by intermolecular $\mathrm{N}-\mathrm{H} \cdots \mathrm{Br}$ hydrogen bonds (dashed lines).

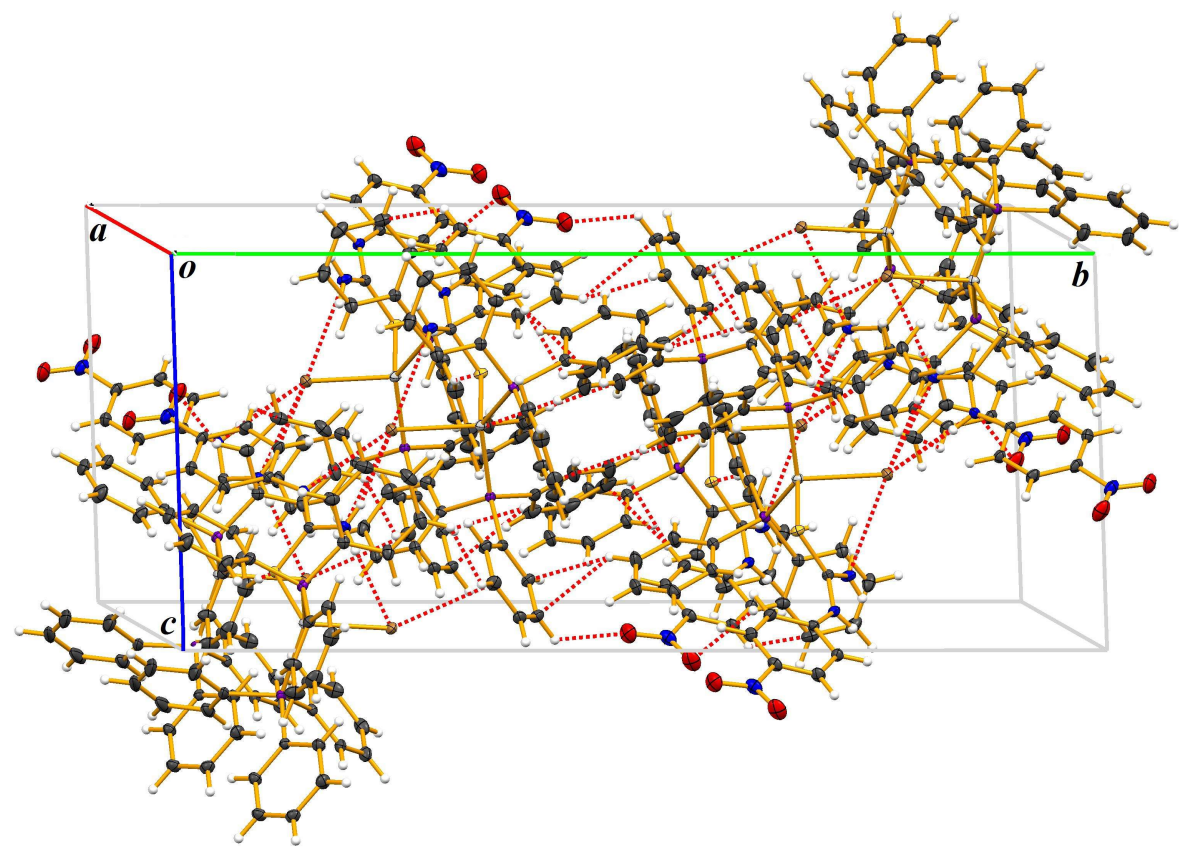

Fig. 3 Part of the crystal structure of $\left[\mathrm{AgBr}(\mathrm{NPTU})\left(\mathrm{PPh}_{3}\right)_{2}\right]$, showing intermolecular $\mathrm{N}-\mathrm{H} \cdots \mathrm{Br}$ and $\mathrm{C}-\mathrm{H} \cdots \mathrm{O}$ hydrogen bonds (dashed lines).

$\mathrm{Cu}-\mathrm{P}$ bond lengths of 2.2687 (4)-2.2758 (5) are similar to the values of 2.2602 (4)-2.2671 (4) $\AA$ for $\left[\mathrm{CuCl}\left(\mathrm{C}_{7} \mathrm{H}_{7} \mathrm{~N}_{3} \mathrm{O}_{2} \mathrm{~S}\right)\left(\mathrm{C}_{18} \mathrm{H}_{15} \mathrm{P}\right)_{2}\right.$ ] [10]. In compound (2), the $\mathrm{Ag}-\mathrm{S}$ bond length of 2.6231 (3) is similar to the bond length of 2.6316 (5) found in $\left[\mathrm{AgCl}\left(\mathrm{C}_{7} \mathrm{H}_{7} \mathrm{~N}_{3} \mathrm{O}_{2} \mathrm{~S}\right)\left(\mathrm{C}_{18} \mathrm{H}_{15} \mathrm{P}\right)_{2}\right][11]$. The $\mathrm{Ag}-\mathrm{P}$ bond lengths of $2.4327(3)-2.4373$ (3) are close to the values of 2.4807 (9)-2.4657 (9) $\AA$ for 
$\left[\mathrm{AgBr}\left(\mathrm{C}_{3} \mathrm{H}_{6} \mathrm{~N}_{2} \mathrm{OS}\right)\left(\mathrm{C}_{18} \mathrm{H}_{15} \mathrm{P}\right)_{2}\right][17]$.

In the crystals of (1) and (2), the amine $\mathrm{NH}_{2}$ moieties of NPTU and $\mathrm{Br}$ atom of neighboring molecules are linked through bifurcated intermolecular $\mathrm{N}-\mathrm{H} \cdots$ Br hydrogen bonds, $\mathrm{N} 1-\mathrm{H} 1 \cdots \mathrm{Br} 1$ and $\mathrm{N} 2-\mathrm{H} 2 A \cdots \mathrm{Br} 1$ for (1) and $\mathrm{N} 1-\mathrm{H} 1 A \cdots \mathrm{Br} 1$ and $\mathrm{N} 2-\mathrm{H} 2 \cdots \mathrm{Br} 1$ (2), forming 1D zigzag chain along [001] (graph set motif $\left(R_{1}^{2}(6)\right.$ [18]) (Fig. 2). The chains are in turn connected by $\mathrm{C}-\mathrm{H} \cdots \mathrm{O}$ hydrogen bonds, $\mathrm{C} 12-\mathrm{H} 12 \cdots \mathrm{O} 2$ and $\mathrm{C} 35-\mathrm{H} 35 \cdots \mathrm{O} 1$ hydrogen bonds for (1) and $\mathrm{C} 24-\mathrm{H} 24 \cdots \mathrm{O} 2$ and

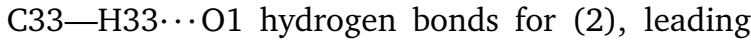
to the formation of a three-dimensional network (Fig. 3 and Table 2).

\section{CONCLUSIONS}

The compounds $\left[\mathrm{MBr}(\mathrm{NPTU})\left(\mathrm{PPh}_{3}\right)_{2}\right](\mathrm{M}=\mathrm{Cu}$ (1) and $\mathrm{Ag}(2))$ were prepared from MBr:NPTU: $\mathrm{PPh}_{3}$ in 1:1:2 molar ratios in acetonitrile. Structures of the complexes were determined using single crystal X-ray diffraction analysis which display a distorted tetrahedral coordination with two $\mathrm{PPh}_{3}$ ligands, NPTU ligand and bromide ion. In the crystals, there are intra and inter-molecular hydrogen bonds leading to the formation of a three-dimensional network.

Acknowledgements: Financial support from the Department of Chemistry, Faculty of Science, Prince of Songkla University, is gratefully acknowledged. We would like to thank Dr. Matthias Zeller and Purdue University for assistance with the X-ray structure determination and use of equipment based on funding by the National Science Foundation of the United States (CHE-1625543).

\section{REFERENCES}

1. Hollmann K, Oppermann A, Witte M, Li S, Amen M, Flörke U, Egold H, Henkel G, et al (2017) Copper(I) complexes with thiourea derivatives as ligands: Revealing secrets of their bonding scheme. Eur J Inorg Chem 2017, 1266-1279.

2. Ahmad S, Isab AA, Perzanowski HP (2002) Silver(I) complexes of thiourea. Transit Met Chem 27, 782-785.

3. Piro OE, Castellano EE, Piatti RCE, Bolzán AE, Arvia AJ (2002) Two thiourea-containing gold(I) complexes. Acta Cryst C 58, 252-255.

4. Nadeem S, Rauf MK, Ahmad S, Ebihara M, Tirmizi SA, Bashir SA, Badshah A (2009) Synthesis and characterization of palladium(II) complexes of thioureas. X-ray structures of $\left[\mathrm{Pd}\left(N, N^{\prime}\right.\right.$ dimethylthiourea) $\left.{ }_{4}\right] \mathrm{Cl}_{2} \cdot 2 \mathrm{H}_{2} \mathrm{O}$ and [Pd(tetramethylthiourea) $\left.{ }_{4}\right] \mathrm{Cl}_{2}$. Transition Met Chem 34, 197-202.

5. Li Z-X, Liu X-Q, Zhao T-Q, Geng P-F, Guo W-G, Yu B, Liu H-M (2017) Design, synthesis and preliminary biological evaluation of new [1,2,3]triazolo[4,5d]pyrimidine/thiourea hybrids as antiproliferative agents. Eur J Med Chem 139, 741-749.

6. Liu P, Shu C, Liu L, Huang Q, Peng Y (2016) Design and synthesis of thiourea derivatives with sulfurcontaining heterocyclic scaffolds as potential tyrosinase inhibitors. Bioorg Med Chem 24, 1866-1871.

7. Drzewiecka-Antonik A, Rejmak P, Klepka MT, Wolska A, Pietrzyk P, Stępień K, Sanna G, Struga MJ (2017) Synthesis, structural studies and biological activity of novel $\mathrm{Cu}(\mathrm{II})$ complexes with thiourea derivatives of 4-azatricyclo[5.2.1.0 $0^{2,6}$ ]dec-8-ene-3,5-dione. $J$ Inorg Biochem 176, 8-16.

8. Chetana PR, Srinatha BS, Somashekar MN, Policegoudra MN (2016) Synthesis, spectroscopic characterisation, thermal analysis, DNA interaction and antibacterial activity of copper(I) complexes with $N, N^{\prime}$ disubstituted thiourea. J Mol Struct 1106, 352-365.

9. Segura DF, Netto AVG, Frem RCG, Mauro AE, Leite CQF (2014) Synthesis and biological evaluation of ternary silver compounds bearing $N, N$-chelating ligands and thiourea: X-ray structure of $[\{\mathrm{Ag}(\mathrm{bpy})(\mu$ $\left.\mathrm{tu})\}_{2}\right]\left(\mathrm{NO}_{3}\right)_{2}$ (bpy = 2,2'-bipyridine; $\mathrm{tu}=$ thiourea $)$. Polyhedron 79, 197-206.

10. Nimthong-Roldán A, Promsuwhan N, Puetpaiboon W, Wattanakanjana Y (2017) Crystal structure of chlorido[1-(4-nitrophenyl)thioureakS ] bis(triphenyl phosphane-кP)copper(I). Acta Cryst E 73, 41-44.

11. Nimthong-Roldán A, Sripa $P$, Wattanakanjana Y (2017) Crystal structure of chlorido[1-(4nitrophenyl)thiourea- $\kappa S$ ] bis(triphenylphosphane$\kappa P)$ silver(I). Acta Cryst E 73, 829-831.

12. APEX3 v9-0 (2016), Saint V8.34A, Saint V8.37A.

13. SHELXTL Suite of Programs, v6.14 (2000-2003).

14. Sheldrick GM (2008) A short history of SHELX. Acta Cryst A 64, 112-122.

15. Sheldrick GM (2015) Crystal structure refinement with SHELXL. Acta Cryst C 71, 3-8.

16. Hübschle CB, Sheldrick GM, Dittrich BJ (2011) ShelXle: a Qt graphical user interface for SHELXL. $J$ Appl Cryst 44, 1281-1284.

17. Pakawatchai C, Jantaramas P, Mokhagul J, Nimthong $\mathrm{R}$ (2012) (1-Acetylthiourea- $\kappa S$ )bromidobis(triphenylphosphane-кP)silver(I). Acta Cryst E 68, 1506-1507.

18. Etter MC, MacDonald JC, Bernstein J (1990) Graphset analysis of hydrogen-bond patterns in organic crystals. Acta Cryst B 46, 256-262.

19. Macrae CF, Bruno IJ, Chisholm JA, Edgington PR, McCabe P, Pidcock E, Rodriguez-Monge L, Taylor R, et al (2008) Mercury CSD 2.0 - new features for the visualization and investigation of crystal structures. J Appl Cryst 41, 466-470.

20. Westrip SPJ (2010) publCIF: software for editing, validating and formatting crystallographic information files. J Appl Cryst 43, 920-925. 